\title{
Determinants of small-scale farmers' choice and adaptive strategies in response to climatic shocks in Vhembe District, South Africa
}

\author{
Zongho Kom $(D)$ N. S. Nethengwe $\cdot$ N. S. Mpandeli $\cdot$ H. Chikoore
}

Published online: 13 August 2020

(C) The Author(s) 2020

\begin{abstract}
Climate change is one of the multiple challenges facing all categories of farmers globally. However, African farmers are the most sensitive in respect of climate variability and change. Climate change impacted negatively on crop production and the livelihoods of the local farmers. In black township South Africa, agricultural activities are highly dominated by small-scale farmers, whose farming system is highly vulnerable to changes in climate. This paper presents the analysis of how small-scale farmers employed adaptation strategies in response to climate change and determinants of small-scale households' choices of coping and adaptation approach to climate variability and change in Vhembe District, South Africa. Multi nominal logit model was used on a surveyed of 224 local farmers. Farmers' socio-economic attributes, was used in response to climate changes and further, households have adaptation strategies both on-farm and off-farm approach. Such approaches were; drought-tolerant seeds, shorter cycle crops, diversification of crops, changing planting
\end{abstract}

Z. Kom $(\bowtie) \cdot$ N. S. Nethengwe .

N. S. Mpandeli · H. Chikoore

Deparment of Geography and Geo-Information Sciences, University of Venda, Private Bag X5050, Thohoyandou, Limpopo Province 0950, South Africa

e-mail: zogokom@yahoo.fr

\section{N. S. Mpandeli}

Water Research Commission, University of Venda, Thohoyandou, Limpopo Province, South Africa dates, small-scale irrigation, migrating to urban areas and involvement in petty business. The results of the findings reveals that the significant drivers affecting choice of adaptation approach include climate information, gender, farm size, education level, farmer experience, decreasing rainfall and increases in temperature as farmers' determinant choices of adaptation to climate change. While, on the other hand, off-farm resources, headed households and age had no significant impact on the choice of coping and adaptation approach to climate change. Therefore, policy makers in the local municipality should play a significant role by enhancing adaptation strategies appropriate for particular climatic shock on the study area.

Keywords Climate change - Adaptation strategies . Small-scale farmers $\cdot$ Vhembe District $\cdot$ Multi nominal logit (MNL) model

\section{Introduction}

Climate change is one of the major challenges facing all categories of farmers globally. Therefore, climate change is a challenge to agricultural yield and food security of the developing world in multifaceted ways, which require both environmentally-friendly and scientific adaptation strategies. Agriculture production is vulnerable to climate variability and change in Africa. Several studies reported that, this is due to the 
effect of climate shocks such as erratic rainfall, temperature increase, prolonged drought, heatwave and humidity (IPCC 2007, 2011). Scarcity of water for farming remains a major dilemma for food production and sustainable development (Kahinda and Taigbenu 2011). These have affected small-scale farmers in Sub-Saharan Africa, whose agricultural production relied on rain-fed for their livelihoods (Anderson et al. 2010; Alemayehu and Bewket 2017). Further, food insecurity is mainly caused by changes in rainfall and increase temperature, which brings about prolonged dry spells periods of climate stress on farming systems (Chazovachii 2012; Domenech 2015).

In Sub-Sahara Africa, an estimated $70 \%$ of smallscale farmers depend mainly on agriculture as their mainstay of livelihoods (FAO, IFAD and WFP (2015). Several studies confirmed that small-scale farming activities are the motor for rural economic growth and welfare for the poor (AGRA 2013; Komba and Muchapondwa 2012; Bryceson 2019). This sector of agriculture promotes accessible nutritious food to support the local community dietary needs, as well as reduce poverty among households and enhance livelihoods (IFAD 2008). Empirical evidence reported that, developing countries and especially Sub-Sahara African countries are the most vulnerable to climate variability and change (Deressa et al. 2009; Barton et al. 2019). This is as a result of changes in climate, which adversely affected agriculture sector and local farming practices of household, resulting to poor crop harvest.

Hence, in South Africa, like in other African Nations, empirical studies indicate that variability and change in climate is a major threat to small-scale farmers' well-being. Studies conducted in Limpopo Province indicated that lack of water and prolonged dry spells in the following years, 1981/1984, 1988/1989, 1991/92, 2004/2005 and lately in 2014/2015 seasons (Mpandeli et al. 2015; Twagiramaria et al. 2018). This had some significant negative effects on crop and animal production, as well as on food security and livelihoods at the rural areas. Karakaya et al. (2014) suggested that these negative threats necessitate the uptake of adaptation strategies and sustainable technological innovations. Maponya (2013) reported that rural farmers in Limpopo Province are faced with challenges of changing climate impacts on agricultural production, hence have developed adaptation options to combat this climate change.

Therefore, several studies conducted in Vhembe district has shown that during prolong drought, most of the time, commercial farmers have wide choice than small-scale farmers (Mpandeli 2006; Maponya and Mpandeli 2013). However, farmers with good financial backups, good irrigation system, such as the centre pivot, also, commercial farmers can easily switch their business to a suitable location easy for adaptation. However, small-scale farmers are most affected due to their high dependency on the climate-sensitive rainfed agriculture sector, limited options and lack of financial resources.

Further accessing adoption and opportunities for effective coping and adaptation strategies are necessary to minimise negative climate shocks at farm level. The choice of adapting within individual farmer is normally determined by the local agricultural cycle that includes seasonal climatic variation as well as other socio-economic drivers (Wood et al. 2014). Hence, adaptation is the ability of a system to respond or adjust to risks or potentials effects of climate variability and change conditions (IPCC 2014). Oni et al. (2012) reported that, small-scale farmers in South Africa including the Vhembe District, use a variety of strategies to manage and adapt to the negative impacts of climate change. Alemayehu and Bewket (2017) argue that sustainability of the agricultural sector in the regions relies on how farmers have employed coping and adaptation strategies toward this change.

However, a basic knowledge of how and why small-scale farmers have responded to past climate change trends is of a vital importance in enhancing recent and future adaptation strategies. Literature have reviewed that, it is an important starting point to analyse adaptive capacity in order to understand how recent changes in climatic conditions are perceived, analysed, interpreted and responded to by local smallscale farmers (Vincent 2007; Mpandeli et al. 2015). Further, Banerjee (2015) reported the importance of enhancing stakeholder policy towards combatting the effects of climate change on small-scale farmers, as well as the importance of some knowledge, perceptions of the local state of climate change and adaptation strategies. Garcia de Jalon et al. (2018) in their studies examined responses of small-scale farmers to climate variability and adaptation strategies in 
Sub-Sahara Africa. Hence, under possible increases in the temperature and a decrease in the rainfall being important climatic variables, the assessment of climate change and the consequent effect on agriculture activities is of paramount important in Vhembe District. Hence, this study investigates climate change negatively impact on small-scale farmers cropping activities, and choice of adaptation responses.

Therefore, a sample survey of 224 local farmers were selected from three ecological zones, which includes 80 farmers from sub-tropical high rainfall, 74 farmers from sub-tropical low rainfall and 70 farmers from trust savannah, as a case study in the District. Data were further administered through questionnaire and focus group discussion. The multi nominal logit (MNL) regression Model was employed, with explanatory variables from socio-demographic attributes and biophysical of the farmers' households. Despite the fact that Levubu, Nwanedi and Tshiombo are highly vulnerable to climate variability and change, farmers should be able to use coping and adaptation approach in order to minimise the negative impact of climate trends on agricultural activities. Several empirical evidence have been conducted in this study area but mainly focus on farmers' perceptions, coping and adaptation strategies in response to climate variability and change. Indeed, on the other hand, few studies have been done as it is known to the author using MNL regression model analysis of smallscale farmers' choice of adaptation approaches in Vhembe district. Therefore, this study's findings are vital for black local farmers to future plan for coping and adaptation approaches and improve their crop production in other area of the District.

\section{Literature review}

\section{Climate change}

Climate change is defined as "'any change in climate over time, whether due to natural variability or as a result of human activity"' (IPCC 2007). The Intergovernmental Panel on Climate Change (IPCC) has further given a more enlarged definition to climate change stating that climate change is "a change of climate which is attributed directly or indirectly to human activity that alters the composition of the global atmosphere and which is in addition to natural climate variability observed over comparable time periods" (IPCC 2014). Extreme temperatures, floods, drought and water scarcity are expected because of global climate change, mainly due to anthropogenic activities which lead to increased GHGs emission, as well as, high temperatures and low precipitations; thereby reducing the availability of food source needed for community livelihoods. This climate variability across the globe will severely affect agriculture. Global warming scenarios mostly bring about a decline in crop yields due to increasing temperature and declining rainfall, and consequently reducing crop quality and increasing food insecurity

However, Africa, for the past decades, has been identified as one of the World most exposed regions to the effects of changes climate (IPCC 2014; Niang et al. 2014). World Bank (2013) reported that about $65 \%$ of Africa's labour force are employed in the agricultural sector and since 2000, there has been an increase of agricultural activities.

Hence, small-scale farmers in the tropics are already facing various threats to agricultural production. Extreme changes in climate are projected to have an adverse effect on local farmers, thus putting the livelihoods of the farmers on further risks. In Africa, farmers tend to be more susceptible to many climatic impacts particularly because of the over reliance on rain-fed farming for their livelihoods. Due to the deepening of climate change stress, more attention has been paid to agriculture vulnerability in Africa because most countries are facing tremendous climate stresses and are more prone to climate change impacts. In developing countries, few studies and empirical evidence have analysed the role national and local government can play in putting up of policies and action to promote and improve adaptive capacity to the changing climate.

\section{Adaptation to climate change}

Adaptation is defined as the "adjustment in natural or human systems in response to actual or expected climatic stimuli or their effects, which moderates harm or exploits beneficial opportunities" (IPCC 2007; UNFCCC 2010). According to this definition, the term "adaptation", involves financial adaptation, socioeconomic and institutional adjustment. Hence, adaptation to climate change has been identified as a set of activities with which a population responds 
accordingly to various pressures resulting from a changing climate (Nyong et al. 2007; Menike and Arachchi 2016). Such responses or adjustments refer to environmental, social or economic, at a system level (IPCC 2014; Komba and Muchapondwa 2015). Therefore, climate change adaptation is considered as an event through which individuals and communities alter their regular ways of life and usual activities as a way to deal with climate change stimuli, irrespective of intent, spatial, temporal and performance (Komba and Muchapondwa 2015; Makuvaro et al. 2018).

However, in Sub Sahara Africa, most small-scale farmers depend on small-scale farming activities for their livelihood and as a major source of food security and resilience (Hou et al. 2015; Garcia de Jalon et al. 2018). The agricultural production environment is characterised by low crop yield, caused by prolonged drought, heatwaves, high temperature, variable precipitation, hence kept Africa's small-scale farmers crop production low and high food insecurity (Maponya and Mpandeli 2013). As reported by Uddin et al. (2017), addressing issues of climate change variability, the focus in recent decades placed more emphasis on minimising the release of greenhouse gases. However, minimal progress has been made in this regard, whilst climate change has persisted thus having negative impacts on agricultural production within various Sub-Sahara African nations. Recently, much attention has shifted from halting greenhouse emissions to adaptation methods that minimize vulnerability to various impacts of a changing climate (IPCC 2010; UNFCCC 2013).

Adaptation to climate change is vital within developing countries. It is a concept that has been a common practice in recent years (Burton et al. 2006; Turpie and Visser 2013). During the commencement of the UNFCCC, mitigation was employed as a strategy to deal with this dilemma. Hence, little attention was given to adaptation. However, international society recognised that mitigation only cannot address climate change, therefore, adaptation was needed to be equally footed with mitigation (Hill 2008; Mubiru et al. 2015). Recently, the concept of adaptation developed into an influential research area for many fields of study (Van Aalst et al. 2008; Obayelu et al. 2014). It has been imperatively adapted as a policy response to the negative effects of climate change together with mitigation, therefore adaptation and mitigation had to be considered equally (Burton et al. 2006; Hill 2008; Devi et al. 2017).

However, the concept of adaptive capacity is closely related to a multitude of commonly employed concepts, such as coping ability, adaptability, robustness, flexibility and resilience change (Jones 2001; Jianjun et al. 2015). Adaptive capacity varies from specific area to area, from local community to community, from farmers to farmers and individuals. This variation depends on its nature and its worth to the particular environment. The magnitude of adaptive aptitude is dependent; the ability of a farmer's household to support climate shocks with a shorter period depends to some degree on the supporting community or environment (Smit and Wandel 2006; Adégnandjou and Barjolle 2018). However, for farmers to undertake adaptation can be affected by such factors such as; farm size, access to information, financial availability, technological, infrastructure, institutional policy and environment (Adger et al. 2001; Smit and Wandel 2006; Ayanlade et al. 2017; Mkonda et al. 2018). Hence, the prime objectives of this study are to investigate adaptation strategies employed by small-scale farmers to combat the negative impacts of climate change and determine drivers that influence small-scale farmers' decisions to adopt adaptation strategies in Vhembe District, South Africa.

\section{Literature review}

\section{Climate change}

Climate change is defined as "' any change in climate over time, whether due to natural variability or as a result of human activity', (IPCC 2007). The Intergovernmental Panel on Climate Change (IPCC) has further given a more enlarged definition to climate change stating that climate change is "a change of climate which is attributed directly or indirectly to human activity that alters the composition of the global atmosphere and which is in addition to natural climate variability observed over comparable time periods" (IPCC 2014).

However, extreme temperatures, floods, drought and water scarcity are expected because of global climate change, mainly due to anthropogenic activities which leads to increased GHGs emission, as well as, 
high temperatures and low precipitations; thereby reducing the availability of food source needed for community livelihoods. This climate variability across the globe will severely affect agriculture. Global warming scenarios mostly bring about a decline in crop yields due to increasing temperature and declining rainfall, and consequently reducing crop quality and increasing food insecurity.

Sub-Sahara Africa countries, in the past decades, has been identified as one of the World most exposed regions to the effects of changes climate (IPCC 2014; Niang et al. 2014). World Bank (2013) reported that, about $65 \%$ of Africa's labour force are employed in the agricultural sector and since 2000, there has been an increase of agricultural activities.

Small-scale farmers in the tropics are already facing various threats to agricultural production. With extreme changes in climate are projected to have an adverse effect on local farmers, thus putting the livelihoods of the farmers on further risks. Empirical studies indicated that, African farmers tends to be more susceptible to many climatic impacts particularly because of the over reliance on rain-fed farming for their livelihoods. Due to the deepening of climate change stress, more attention has been paid to agriculture vulnerability in Sub-Sahara Africa because most countries are facing tremendous climate stresses and are more prone to climate change impacts. In developing countries few studies and empirical evidence have analysed the role national and local government can play in putting up of policies and action to promote and improve adaptive capacity to the changing climate.

\section{Adaptation to climate change}

Adaptation is defined as the "adjustment in natural or human systems in response to actual or expected climatic stimuli or their effects, which moderates harm or exploits beneficial opportunities" (IPCC 2007; UNFCCC 2010). According to this definition, the term "adaptation", involves financial adaptation, socioeconomic and institutional adjustment. Hence, adaptation to climate change has been identified as a set of activities with which a population responds accordingly to various pressures resulting from a changing climate (Nyong et al..2007; Menike and Arachchi 2016). Such responses or adjustments refer to environmental, social or economic, at a system level (IPCC
2014; Komba and Muchapondwa 2015). Therefore, climate change adaptation is considered as an event through which individuals and communities alter their regular ways of life and usual activities as a way to deal with climate change stimuli, irrespective of intent, spatial, temporal and performance (Komba and Muchapondwa 2015; Makuvaro et al. 2018).

However, in Sub Sahara Africa, most small-scale farmers depend on small-scale farming activities for their livelihood and as a major source of food security and resilience (Hou et al. 2015; Garcia de Jalon et al. 2018). Hence, small-scale farmers depend on climate variables, particularly precipitation and temperature (IPCC 2007; FAO 2008). The agricultural production environment is characterised by low crop yield, caused by prolonged drought, heatwaves, high temperature, variable precipitation, hence kept Africa's small-scale farmers crop production low and high food insecurity (Maponya and Mpandeli 2013). As reported by Uddin et al. (2017), addressing issues of climate change variability, the focus in recent decades placed more emphasis on minimising the release of greenhouse gases. However, minimal progress has been made in this regard, whilst climate change has persisted thus having negative impacts on agricultural production within various Sub-Sahara African nations. Recently, much attention has shifted from halting greenhouse emissions to adaptation methods that minimize vulnerability to various impacts of a changing climate (IPCC 2010; UNFCCC 2013).

However, adaptation to climate change is vital within developing countries, where it is not a new phenomenon in the climate context. It is a concept that has been a common practice in recent years (Burton et al. 2006; Turpie and Visser 2013). During the commencement of the UNFCCC, mitigation was employed as a strategy to deal with this dilemma, so little attention was given to adaptation. However, as a vital policy reaction to effects of changes in climate together with mitigation. The international society recognised that mitigation only cannot address climate change, therefore, adaptation was needed to be equally footed with mitigation (Hill 2008; Mubiru et al. 2015). Recently, the concept of adaptation developed into an influential research area for many fields of study (Van Aalst et al. 2008; Obayela et al. 2014). It has been imperatively adapted as a policy response to the negative effects of climate change together with mitigation, therefore adaptation and mitigation had 
to be considered equally (Burton et al. 2006; Hill 2008; Devi et al. 2017).

Further, the concept of adaptive capacity is closely related to a multitude of commonly employed concepts, such as coping ability, adaptability, robustness, flexibility and resilience change (Jones 2001; Jianjun et al. 2015). Adaptive capacity varies from specific area to area, from local community to community, from farmers to farmers and individuals. This variation depends in terms of its nature and its worth to the particular environment. The magnitude of adaptive aptitude is dependent; the ability of a farmer's household to support climate shocks with a shorter period depends to some degree on the supporting community or environment (Smit and Wandel 2006; Adegnandjou et al. 2018). However, for local farmers to undertake adaptation can be affected by such drivers as farm size, access to information, financial availability, technological, infrastructure, institutional policy and environment within adaptation occurs and political will (Adger et al.2001; Smit and Wandel 2006; Ayanlade et al. 2017; Mkonda et al. 2018). The prime objective of this study here to investigate the negative impact of climate change on small-scale farmers' activities and, to identify determined of adaptation choice to climate change.

\section{Methods}

Description of the study area

This study covers three sites which are slightly difference in agroecological zone, there are; Levubu, Nwanedi and Tshiombo in Vhembe District. The district municipality is situated in the extreme northern part of Limpopo Province, with agricultural activities as the main occupation of the local black communities. This District is subdivided into four municipal areas (Fig. 1), namely, Makhado, Musina, Thulamela and Mutale (Demarcation Board 2002). However, this study area is characterized by mean annual rainfalls of 400-900 mm; with winter being dry with frequent frost in some areas, while the mean annual temperature ranges from 9 to $17{ }^{\circ} \mathrm{C}$ during winter and 22-37 ${ }^{\circ} \mathrm{C}$ during summer season. Mpandeli and Maponya (2013) cited that Vhembe district is geographically located in a semi-arid area, which affected by longer dry spells and as a result grow into severe drought conditions Statistics South Africa (2011) the population of the District was estimated at 1,232,218 and a density of 70 per $\mathrm{km}^{2}$ which is predominantly rural and its livelihood depends on an agriculture production which is sensitive to climate variability and change.

This District is situated in the eastern subtropical region and is generally hot and humid, receiving the bulk of its annual rainfall in November through March as the Inter Tropical Convergence Zone (I.T.C.Z) moves South (Kabanda 2004). This District Municipality, Specific climatic conditions have influence agriculture activities and crop yield as production highly dependent on climate variables.

The agro-ecological setting of these areas is dominated by the inter-tropical convergence zone climatic conditions (Munyati and Kabanda 2009). As a result, the climate is typically subtropical with mild, moist winters and wet, warm summers. The climatic conditions influence diverse farming activities which, can be directly linked to the dualistic nature of the agrarian patterns in the district, which compromises the livelihoods of the district's rural farmers. The district agrarian system is divided into the wellestablished white commercial horticulture farming in the south eastern side (Makhado Levubu area), and the small scale farming by blacks in the barren land of Thulamela and Musina, to the north to far north of the district.

Vhembe District Municipality has a total area of 2,140,708 hectares, of which 247,757 hectares are arable land. The agricultural system in the district is divided into two types, that is, large scale commercial farming and small-scale farming as known as smallscale farmers or subsistence (VDM 2011/12 IDP Review). Approximately $70 \%$ of the arable land is owned by white farmers while only $30 \%$ of arable land belongs to a small group of local farmers who are mostly dominated by black farmers. The district has two existing agro-ecology locations which are: Levubu and Nwanedi valleys (VDM 2011/12 IDP Review). This study focuses on the impacts of climate change on small-scale farming over the period of 1980-2015, and it impacts on small-scale farmers. Part of the VDM lies on the gentle slopes and in the valleys of the Soutpansberg mountain ranges (Niang et al. 2014). The valleys receive heavy rainfall from the month of November to March. The alluvial soil is very fertile and easily worked, which is suitable to 


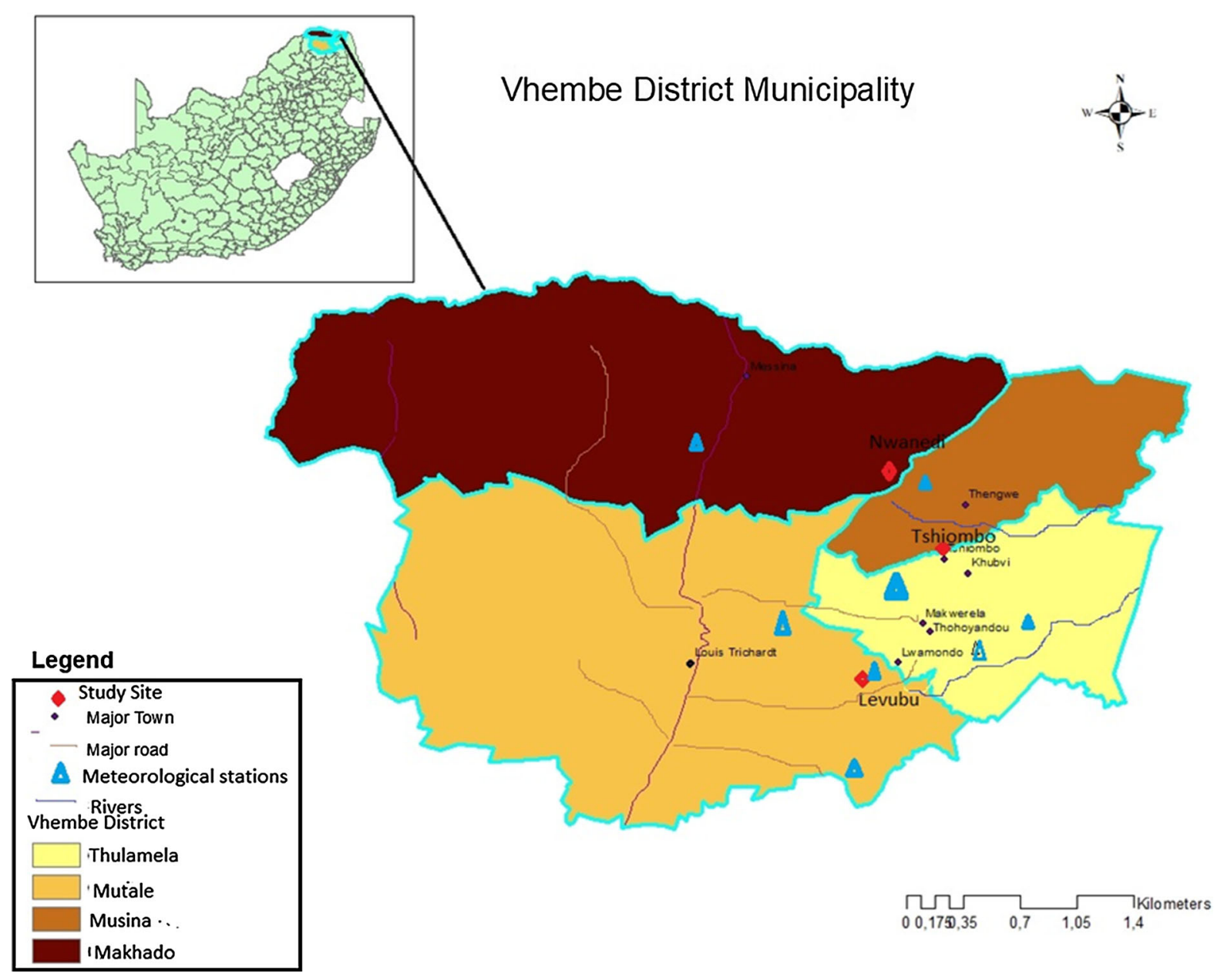

Fig. 1 Location of the study sites and Meteorological stations

farm many sub-tropical products such as sweet potatoes, beans, vegetables, maize, tomatoes and pumpkins (Magombo et al. 2011).

Data and methods

\section{Data collection}

This study used both quantitative and qualitative as research design. Hence, before the collection of data at the study sites, a sample size was obtained from community members engaged in small-scale farming activities. The sample size was obtained from farmers households by selecting every $Z$, where $X$ stands for the total number of farmers at the study sites and $n$ was the sample size preferred (Saunders 2011). For this study, this sample size is needed to reduce costs and time, and environmental limitations of the dispersed farmers. To determine precision and accuracy, criteria were used to determine the appropriate sample size. A confidence level of $95 \%$ and $5 \%$ level of correctness were used for the survey. However, to lessen bias and mistakes and increase validity, so that inferences can be made for the whole target unit of analysis. Therefore, a total of 236 questionnaires were administered. However only 228 were collected from the respondents and 224 questionnaires were effectively completed and used for analyses.

\section{Descriptive data analysis}

The study selected information from the field such as; demographic, socio-economic attribute and climatic indicators. After the data survey, it was entered into a 
statistical excel spreadsheet for cleaning and analysis. Hence, MNL was employed to analyse the drivers influencing small-scale famers' choices of adaptation strategies to changes in climate in Vhembe District. MNL framework is used as methods of adaptation choice. Magombo et al. (2011), stated that the relationship between the probability of choosing and adaptation preference and the explanatory variable. This MNL framework was frame to the adoption choice of climate change adaptation, the study further indicated that, MNL framework have the advantage that it brings the analysis of adoption among several strategies of adaptation.

Let $\mathrm{Z}$ signify a random variable with values $\{1,2 \ldots$ $J\}$ for a positive integer $J$ and $X$ set of variables. In this study, $\mathrm{Z}$ is a dependent variable and represents the adaptation, choices methods from the set of adaptation measures, whereas, the $\mathrm{X}$ represents the dynamics that effect choice of the adaptation strategies which contains household attributes as described in Table 1, and $\mathrm{P} 1, \mathrm{P} 2 \ldots \mathrm{PJ}$ as associated probabilities such that $\mathrm{P} 1+\mathrm{P} 2 \ldots+\mathrm{PJ}=1$. This tells how a certain change in $X$ factors affects the response probabilities $P(y=j /$ $\mathrm{x}), \mathrm{j}=1,2 \ldots \mathrm{J}$. Since the probabilities must sum to unity, $P(Z=j / x)$ is determined once the probabilities for $\mathrm{j}=2 \ldots \mathrm{J}$ are known;

$\mathrm{P}(\mathrm{Z}=1 / \mathrm{x})=1-(\mathrm{P} 2+\mathrm{P} 3+\cdots \mathrm{Pj})$

MNL framework, it is usual to designate one as the reference category. The probability of membership in other categories is then compared to the probability of membership in the reference category. Consequently, for a dependent variable with $\mathrm{j}$ categories, this requires the calculation of $\mathrm{j}-1$ equation, one for each category relative to the reference category, to describe the relationship between the dependent variable and the independent variable. The choice of the reference category is arbitrary but should be theoretically motivated. The estimation of MNL framework for this study was conducted by normalising one category which is named as base category or reference estate. The adaptation measures were grouped into eight because farmers used more than one strategy, and the base category was "No adaptation strategy". The theoretical explanation of the framework is that in all cases, the estimated coefficient should be compared with the bas group or reference category. Therefore, the choice of the reference category is based on empirical literature and theoretically motivated. The generalized form of probabilities for an outcome variable with $\mathrm{j}$ categories is:

$$
\begin{aligned}
& \operatorname{Pr}\left(\mathrm{y}_{\mathrm{i}}=\mathrm{j} \mid \mathrm{x}\right)=[\operatorname{pr}]_{\mathrm{ij}}=\left(\exp \left(x^{\prime} \quad \beta \mathrm{j}\right)\right) \\
& \quad /\left(1+\sum_{(\mathrm{j}=2)}^{\mathrm{j}}\left[\exp \left(\begin{array}{ll}
x^{\prime} & \beta \mathrm{j})
\end{array}\right]\right), \quad \mathrm{j}=1,2 \ldots \mathrm{J}\right.
\end{aligned}
$$

For $\mathrm{j}>1$.

The parameter estimation of the MNL framework only provides the direction of the effect of the independent variables on the dependent (response) variable, estimates represent neither the actual magnitude of change nor probabilities. Differentiating Eq. 2 with respect to the explanatory variable provides the marginal effect of the independent variables, Eq. 3 which gives as:

$\partial \mathrm{pi} / \partial \mathrm{xk}=\mathrm{pj}\left(\beta \mathrm{jk}-\sum_{(\mathrm{j}=1)}^{(\mathrm{j}=1)} \mathrm{pj} \beta \mathrm{jk}\right)$

Marginal effect of marginal probabilities is the function of probabilities and measures the expected change in probabilities where particular adaptation choice is being made by a unit change of the independent variable from the mean.

\section{Results and discussion}

Farmers' demographic and socio-economic attributes in response to climate change

\section{Gender}

The results of this study revealed that, out of the final population sample of 224 respondents, $54.9 \%$ were female, while, $45.1 \%$ were male as shown in Table 1 , hence, agricultural activities were predominantly carried out by female farmers. The findings indicate that females comprised most of the small-scale farmers in the study sites and were mostly household scaleheaded. These results are similar to findings in Limpopo province, of South Africa (Mpandeli 2006). Households headed by females' farmers are most likely to employ new crops and diversification, response to climate variability and change. These findings are in line with this study conducted by Nhemachena and Hassan 
Table 1 Demographic and socio-economic attributes of the farmers' households

\begin{tabular}{|c|c|c|c|c|c|c|c|c|}
\hline \multirow[t]{2}{*}{ Variables } & \multicolumn{2}{|c|}{ Levubu } & \multicolumn{2}{|c|}{ Tshiombo } & \multicolumn{2}{|c|}{ Nwanedi } & \multicolumn{2}{|c|}{ Total } \\
\hline & No & $(\%)$ & No & $(\%)$ & No & $(\%)$ & No & Percent \\
\hline Number of household interview & 62 & 30.8 & 68 & 33.8 & 71 & 35.3 & 201 & 100 \\
\hline \multicolumn{9}{|l|}{ Gender } \\
\hline Female & 34 & 58.8 & 37 & 54.4 & 40 & 56.3 & 111 & 55.2 \\
\hline Male & 28 & 41.2 & 31 & 45.6 & 31 & 43.7 & 90 & 44.8 \\
\hline \multicolumn{9}{|l|}{ Size of household } \\
\hline $1-4 \mathrm{~h}$ & 48 & 77.4 & 55 & 80.8 & 53 & 74.6 & 156 & 77.6 \\
\hline $5-8 \mathrm{~h}$ & 14 & 22.6 & 13 & 19.2 & 28 & 25.4 & 52 & 25.8 \\
\hline \multicolumn{9}{|l|}{ Farming experience(years) } \\
\hline $10-20$ & 43 & 69.4 & 39 & 57.4 & 47 & 66.2 & 129 & 64.2 \\
\hline $21-30$ & 19 & 30.6 & 29 & 42.6 & 24 & 33.8 & 72 & 35.8 \\
\hline \multicolumn{9}{|l|}{ Age of household head } \\
\hline $31-40$ & 10 & 16.2 & 9 & 13.2 & 11 & 15.5 & 30 & 14.9 \\
\hline $41-50$ & 23 & 37.1 & 25 & 36.8 & 30 & 42.3 & 78 & 38.8 \\
\hline $51-60$ & 19 & 30.6 & 21 & 30.9 & 18 & 25.4 & 58 & 28.9 \\
\hline $61+$ & 10 & 16.2 & 13 & 19.1 & 12 & 16.9 & 35 & 17.7 \\
\hline \multicolumn{9}{|l|}{ Marital status } \\
\hline Single & 30 & 48.3 & 35 & 51.5 & 38 & 53.5 & 103 & 51.2 \\
\hline Married & 11 & 17.7 & 10 & 14.7 & 11 & 15.5 & 32 & 15.9 \\
\hline Widowed & 12 & 19.3 & 9 & 13.2 & 12 & 16.9 & 33 & 16.4 \\
\hline Divorced & 9 & 14.5 & 14 & 20.6 & 10 & 14.1 & 33 & 16.4 \\
\hline \multicolumn{9}{|l|}{ Educational level } \\
\hline Non-formal education & 23 & 37.1 & 28 & 41.2 & 34 & 47.9 & 85 & 42.3 \\
\hline Grade $1-8$ & 25 & 40.35 & 26 & 38.2 & 27 & 38 & 78 & 38.8 \\
\hline Grade $9-12$ & 7 & 11.3 & 6 & 8.8 & 5 & 7.1 & 18 & 8.9 \\
\hline Certificate/Diploma & 5 & 8.1 & 7 & 10.3 & 4 & 5.6 & 16 & 7.9 \\
\hline University & 2 & 3.2 & 1 & 1.5 & 1 & 1.4 & 4 & 1.9 \\
\hline \multicolumn{9}{|l|}{ Household income (ZAR/month) } \\
\hline Below 1500 & 17 & 27.4 & 22 & 32.4 & 26 & 36.6 & 65 & 32.3 \\
\hline $1600-2500$ & 23 & 37.1 & 26 & 38.2 & 25 & 35.2 & 74 & 36.8 \\
\hline $2600-3500$ & 15 & 24.2 & 11 & 16.2 & 9 & 12.75 & 35 & 17.4 \\
\hline $3600+$ & 7 & 11.3 & 9 & 13.2 & 11 & 15.5 & 27 & 13.4 \\
\hline
\end{tabular}

(2007), confirmed that households headed by women have the capacity to take up climate change adaptation strategies. This as a result of their exposure to climate information system and also been activity in farming activities. On the other hand, households headed by males' farmers, were more likely to migrate to nearby urban areas like Thohoyandou, Makhado, and Polokwane, and even as far as Gauteng Province for jobs opportunities. Buyinza and Wambede (2008) however, argue that households headed by male farmers do employ improved adaptation techniques against climate variation. Further, studies in West Africa, confirmed that there is a higher probability of adopting agricultural technologies among households headed by men, due to the higher levels of education by men-headed households (Odekunle et al. 2005; Adégnandjou and Barjolle 2018). The finding of the study indicated that high levels of education enable men to be relatively flexible in adopting new crops and hybrid improved seeds, and using climate knowledge. This was the same case with smallholder farmers in Levubu, Nwanedi and Tshiombo, where farmers have adopted strategies in response to climate variability and change. 


\section{Farmer's household head}

As regarding to househead, the result indicated that, out of the 224 farming households, $37.5 \%$ represents the age group of 41-50 years, followed by an older age group of 51-60 with only $28.6 \%$; elderly household heads aged above 61 years only made up $18.3 \%$, while, the 31-40-year group made up a total of $15.6 \%$ of the informants. The fact that more than $85 \%$ of the household heads were above 41 years of age enhanced the reliability and depth of data elicited as the information required span a period of over 35 years. A similar study carried out in Nigeria by Obayelu et al. (2014), showed that, socio-economic aspects on choices of climate change affect farmers and adaptation to climate variation can be influenced by household age and that, older farmers were more active in farming activities than youths. The youth have less interest in agricultural activities, as they see it as older people's occupation. Moreover, older farmers are interested in following traditional techniques with which they are comfortable than adopting western system of agriculture. These findings confirm results of studies conducted by Acquah (2011) and Uddin et al. (2014). One can conclude, therefore, that current farm techniques could disappear with time as the older generation are the custodians of indigenous knowledge, hence, the youth should be considered for training in these agricultural activities for the future.

\section{Marital status}

Another socio-economic factor which influence climate variability and change was marital status. The marital status of farmers showed that about $48.2 \%$ were single, $16.5 \%$ were married, $17.4 \%$ divorced, indicated that there is a higher level of unmarried households in the study area. It was noted that married households were more productive and active than the single or divorced households. The married families have a large household sizes which provide the needed labour.

\section{Farmers' household size}

This study also indicated that small-scale farmers' household sizes was important as an adaptation driver against changes in climate. As the size comprised of 1-4 members, according to a field survey; this represents $72.3 \%$ of the total farming population in the study area, while household sizes of 5-8 individuals represent $27.7 \%$ of the total respondents, as shown in Table 5. According to the Living Conditions Survey of Households 2014/2015 Statistics South Africa (2017), the average household size in South Africa was 3.3, which correlates with the results of this study. This study further showed that there is no significant difference in Levubu, Nwanedi, and Tshiombo, when comparing household sizes. Large family' size, with a large labour force, may decide to divert some of this force to off-farm production, to earn extra income, to reduce consumption pressure caused by a large household. Zizinga et al. (2017), conducted a study on farmers' choice of adaptation method in response to climate trend in South Western Uganda and their findings revealed that household labour sizes plays a vital role in the adaption of particular adaptation techniques. Household sizes, in terms of the number of people staying in the household, who provide the labour force as an input for agricultural activities, usually manual labour, has an impact on production. This narrative is also consistent with results by Balew et al. (2014). This has lead to smallholder farmers in Vhembe community increasing their family size as means of increasing agricultural production.

\section{Household income}

As indicated in Table 1, the result indicated that an average household income per month was also relevant, as it influences some variables, such as availability of farm inputs, like fertilizers and hybrid seed. There were four groups of income levels. The findings reveal that $31.7 \%$ of household received below ZAR 1500 per month, while $35.7 \%$ were receiving income between ZAR 1600-2500, and $18.8 \%$ respondents received between $2600-3500$, with only $13.8 \%$ who were getting above ZAR 36,000 per month. The study showed that income from agriculture was a major household economic resource. As, the analysis had indicated that farm income for the household has an important impact on improving crop varieties and buying of improved seed varieties. When the major income is increased, farmers tend to invest in products such as buying of chemicals and improved seed varieties and getting involved in crop diversification. This study is in line with previous work by Maponya 
and Mpandeli (2013) and Ayanlade et al. (2017). This is likely to be true with smallholder farmers in the study sites, as some crops require some fertilizer and pesticide application to improve farmers' harvest.

\section{Education level}

Additionally, primary data from the fieldwork have shown that some respondents did not receive any formal education, represented by $50.7 \%$. Another $30.3 \%$ attended the basic level of education-grade one to eight-while $8.9 \%$ and $7.9 \%$ have Grades $9-12$ and certificate levels, respectively; about $1.9 \%$ reported possessing university level qualifications. The results of the study reveal the importance of education for accurately perceiving climate changes. Better levels of educational lead to stronger positive impacts on farmers' perceptions of changes climate. This shows that educated farmers have a better understanding of climate change and are more likely to use advanced means of adaptation strategies to improve their agricultural products; this was hypothesised as a determinant of adaptation to climate variation. This finding concurs with several studies in Africa (Hassan and Nhemachena 2008; Makuvaro et al. 2018). The results further confirm that attaining higher education levels predisposes individuals to better farming experience and awareness of the benefits; it also fosters a willingness to undergo training and acquire new knowledge about climate variability and change.

\section{Farming experience}

Further, the number of years a farmer has spent cultivating crops on a farm is considered as his/her agricultural experience. Possessing many years of farming experience implies that one is better informed about climate variability and change in relation to crop produce, in the study areas, hence, experienced farmers are likely to use adaptation strategies which had reduced the effects of change and improved crop production. Adégnandjou and Barjolle (2018), thus concluded that farming experience help with the easy implementation of any adaptation techniques. This study also revealed that households with experience in agricultural production of not less than 10 years, had a minimum age of 31 years. These findings disagree with studies by Hassan and Nhemachena (2008), who argue that, the age of a farmers does not matter when it involves adaptation methods for climate variation, but rather the number of years involved in farming activities that count the most.

Farmers adaptation strategies in response to climate change at farm level

Regarding to South Africa, farmers have had to adopte different strategies to overcome climate change and variability as farming is the main occupation of the majority of the local black community. Based on the present survey data collected from 224 smallholder farmers, using focus-group discussion and semistructure interview, the researcher analysed the participants' perceptions of climate change issue so as to better understand the coping and adaptation strategies used by smallholder farmers. This is because these farmers' precarious future due to climate change calls for innovative livelihood strategies. The condition is even more acute for the marginalized smallholder farmers in Vhembe District. For the foreseeable future they have no option but to at least, cope with or ideally, adapt to the changing climate.

Across the District, most smallholder farmers attributed reductions in crop yields to rising temperatures and changing precipitation patterns and although the perceived impacts varied across the three study sites, the magnitude of potential climate change impacts on all participants were significant in the last decade. Most commonly observed changes includean increase in temperatures, as stated by $96 \%$ of the respondents; low rainfall by $94 \%$; rainfall variability by $95 \%$ and increased recurrence of drought and floods by $58 \%$. Most of these respondents have also admitted having altered their farming practices to minimize their vulnerability and/or to adjust to the changing weather conditions. These include adopting strategies, such as, diversifying crops and planting new crop varieties. The findings have shown that farmers' perceptions on climate change have had an impact on their livelihoods, as most have consequently changed their farming practices in response to their perceptions (Gandure et al. 2013). Findings from similar studies have also concluded that farmers' perceived changes in their local climatic conditions is a significant driver in the implementation of various adaptive measures and livelihood strategies. 
Table 2 presents that, out of the 224 farmers surveyed in the study sites, $79.1 \%$ have used hybrid improved seeds or have diversified to new crops, as a climate change adaptation strategy over the past three decades. Similar findings were highlighted by Gunathilaka et al. (2018), in a report titled: Adaptation approaches to climate variation in perennial cropping systems options, barriers and policy implication in Sri Lanka. In addition, 59.7\% of participants agreed that cultivation of higher crop production varieties make up for decreased household food; $94.5 \%$ claimed to have adopted planting for shorter cycles, while $98.5 \%$ of the them had shifted planting dates by delaying the planting season for some crops. Similar studies by Epule et al. (2017), showed that changing crop planting dates was employed as a climate change adaptation strategy in the Sahel regions and, due to the prolonged dry spells, $88.6 \%$ of households have adopted crop varieties which are more droughttolerant.

\section{Higher yielding crop varieties}

The result of this study further reveals that rural household farmers have adopted extreme climatic shocks conditions, such as a prolonged dry spell, drought, heatwave, the decline in rainfall, and increase in temperature and shortened the growing season by growing improved hybrid seeds and short cycle crop varieties, hence, thereby slowly abandoning some of their indigenous seed species. Through field survey and focus group discussion, the study discovered that farmers have for the past 20 years slowly abandoned the growing of traditional beans, maize species, and other crop varieties due to yield decline and pest disease attacked on crops. A similar study by Setimela and Kosina (2006) confirmed that respondents in
Vhembe district selected Zm 521 (maize) and Open Pollinated Variety species (OVPs) because of its comparatively high and stable production, resistance to drought and early maturity. Hence, local farmers choice to change from traditional crop to high crop varieties, which is a technique used for disease management and yield improvement. This narrative is also consistent with findings by Dedewrwaerdere and Hannachi (2019) examine socio-economic factors of co-existence of landraces and modern crop varieties in Yannan, China. Similar findings were highlighted that adaptation approaches to climate variation in perennial cropping systems options, barriers and policy implication in Sri Lanka (Gunathilaka et al. 2018).

Despite the perceptions and awareness of climate change challenges to small-scale farmers in the study sites, the focus group discussions and interviews, held with farmers and extension workers revealed that adaptation strategies are similar across all the study sites. It was of paramount interest also to get in-depth data of adaptation and coping strategies from one area to another. Farmers where, all adopted coping strategies that changed their focus to crop varieties of higher potential yields. Each study area further revealed a clear division of the types of crops and crop varieties cultivated. Some of the crops identified as better crops and crop varieties include maize, peanut butter, sweet potatoes, sugar bean, tomatoes and green pepper. In relation to Table 2. Indicated that, $59.7 \%$ of the farmers chose hybrid yield improved maize varieties as crops that have higher yields to replace openpollinated variety maize. For example, local farmers in Tshiombo replaced, some plots of crops with sweet potatoes and green beans. In the study areas, household farmers at Levubu have identified Irish potatoes and improved maize as a higher yielding crop. On the
Table 2 Farm adaptation strategies for rainfall and temperature

\begin{tabular}{llc}
\hline On-farm adaptation strategies & Frequency (No: 224) & Percent \\
\hline Improved new crops/diversification & 159 & 79.1 \\
Higher crop varieties & 120 & 59.7 \\
Drought resistance crop & 178 & 88.6 \\
Changing planting dates & 198 & 98.5 \\
Shorter cycle crops & 190 & 94.5 \\
Intensifying furrow irrigation & 169 & 84.1 \\
Mixed Crops & 187 & 93 \\
Hybrid new crops & 181 & 79.1 \\
\hline
\end{tabular}


other hand, in Nwanedi small-scale reported watermelon and tomatoes as the best choice with higher yielding potential. Finally, for Tshiombo farmers, sweet potatoes were the crop with a very high crop yield and alongside with hybrid maize breeds.

Further, agricultural extension official reported that for a small-scale farmer to accept and cultivate some certain types of maize or beans species, it must be of high yield standard than the local types as well as good taste. The results of the findings also reveal that smallscale famers are shifting to crops with good market prices (Dedewrwaerdere and Hannachi 2019). This good market prices can influence small-scale farmers' decisions on the kind of crop to plant with the intension of getting good income. Therefore, it is important to understand that low crop varieties have low income returns and affects the livelihoods of the majority of small-scale in the Vhembe district. This finding concurs with results of the studies done by Perego (2019) analysis crop prices and land titled in Uganda. However, crop princes have a strong effect when small-scale farmer have access to marketplace.

\section{Drought-resistant crops varieties}

With unpredictable, prolonged dry spells and abnormally increased temperature also contributed to a negative climate change on crops production. However, moisture-stress-tolerant crop varieties were used as an adaptation strategy by small-scale farmers to combat negative impacts of climate on crop during the drought season in the study areas. In relation to the low precipitation, small-scale farmers had to make a choice of crops and crop varieties which are resistant to drought. The data presented through interview and focus group discussion, revealed that; maize, sweet potatoes, beans, and onions, as well as cabbage varieties, were the main crops which varied from one study site to another.

However, during group discussion it was reveals that farmers have changed their planting calendar, and the planting of crop is done only when it rains. The study highlighted that due to numerous drivers, farming from seasons to seasons, farmers had to introduce new crops varieties in the area depending on the climatic conditions. During focus group discussion in Tshiombo, one of the elderly farmer respondents had this to say about introducing of new crops; the growing season for the crop is determined by the climate. If there is no rainfall, then farmers do not plant. These findings are in similar with the studies survey (Komba and Muchapondwa 2012; Mpandeli 2006) in Limpopo River Basin, South Africa. Maponya and Mpandeli (2013) in their studies revealed that farmers used drought-resistant crops as a strategy of adaptation to climate change. This result is in line with the findings of Fisher et al. (2016) highlighted how drought resistant crops promote more climate secure farming in Ananthapur, Andhra Pradesh. In Tshiombo area, sweet potato, onions and beans were adapted as drought-resistant crops in response to harsh climate change. Although these crops are drought resistant most of the small-scale farmers still grow them with irrigation water where possible due to extreme climate.

\section{Changing planting dates and shortening cycle crop varieties}

This study indicated that majority of smallholder farmers preferred employing shorter-cycle crop varieties, to adapt to climate variation, especially, when they were not certain about the local climatic conditions and if they are not accessing climate advisory information well in advance. This strategy was employed by farmers in Levubu, Tshiombo, and Nwanedi, where seasonal rainfall variability has encouraged farmers to adopt crop varieties with shorter cycles and this forms part of climate change adaptation strategies. The continuous climate variations, therefore, have forced smallholder farmers to change planting date patterns, as another adaptation strategy. A similar study conducted by Turpie and Visser (2013), reported that changing planting and harvesting dates are the main strategies smallholder farmers used to adapt to climate change. Acquaah (2011), in line with the present study, mentions that changing planting dates and crop varieties are the frequently preferred adaptation strategies by smallholder farmers in Morogoro, Tanzania. This is in accordance with a similar studies by Singh et al. (2014), on peanuts and cotton in West Africa (Loison et al. 2017), while, Hammer et al. (2002), argue that it is only partially true, since shifting in these indicators should reflect genetic variability.

As indicated, in each study site, crops appeared to be distributed differently-maize remained the main cultivated crop in Tshiombo and around Tshakhuma 
area; Levubu area is well known for producing horticulture crops, whereas, watermelons and tomato varieties are planted in Nwanedi and in Tshiombo sweet potatoes were predominant. Results from the questionnaires testified that, in Tshiombo $64.8 \%$ farmers cultivated improved maize and $45.6 \%$ cultivated improved beans. In Levubu $70.2 \%$ of the farmers cultivated beans, as a shorter-cycle crop and $44.8 \%$ of the farmers in Nwanedi indicated that they had adopted better short-cycle tomato varieties and $40 \%$ were using similar type of new vegetables. These results are similar to findings which highlighted that, variations in planting dates and crop variety in accordance with regions' characteristics as well as the economic factors in relation to the scheduling of operations, were common practices for farmers (Eyshi Rezaei et al. 2015). These findings concur with results of studies done by Hu et al. (2017), who reported that, shifts in cultivar and planting dates have regulated rice growth duration under increasing temperature in China, since the early 1980s. Similar findings were obtained from studies concluded in Southeast Asia, that saw rice farmers shifting to rice with shortened growth duration over the past thirst years (Zhang et al. 2013; Zhao et al. 2016).

During the interviews for this study, farmers maintained that it was now unadvisable to practice early planting because of the low and variable rainfall. They argued that early-planted crops, such as maize and vegetables dry and wither due to prolonged dry spell and extreme heat. This problem is also aggravated by the lack of infrastructure for storage facility. Household farmers reported that in previous years, one would sow seeds during the onset of the rainy season, but the current shorter rainfall season, which now runs from November to February, was forcing farmers to concentrate on shorter-cycle crop varieties. In West Africa, results of studies conducted with regards to the high intra-seasonal rainfall variability, demonstrated that early planting dates can lead to low yields due to extreme weather events which occur shortly after planting (Waongo et al. 2015; Adégnandjou and Barjolle 2018). Late planting dates, although it has been proven can limit poor crops harvest, but the practice also correspond to short growing seasons which in turn can reduce harvests.

Changing planting dates decreases the effects of crop damage or loss from prolonged weather conditions, such as, extreme drought and dry spells, causing an epidemic of crop diseases and insect pests-which in turn result in poor harvests and food insecurity. Similar studies conducted in the Lilongwe District, concluded that farmers in Sub-Sahara Africa, especially, in hot and dry regions, if they plant crop varieties that have short duration for maturity (within 2-3 months), this allows farmers to minimize and evade the damaging effects of moisture-stress on crop yields (Zinyengere et al. 2014), These narrative are also consistent with studies conducted on groundnuts and cotton, in West Africa (Loison et al. 2017; Singh et al. 2017).

\section{Mixed cropping farming}

However, paying attention during field survey and focus group discussions, farmers indicated that most farms respondents employed mixed crop method to adapt to the changing climate. This was one of the traditional farming practices used to improve crop yield. The results in Table 2, reveal that $93 \%$ of farmers in the study areas practiced this farming system. Selected crop types are cultivated simultaneously on the same piece of land by farmers to reduce the depletion of soil nutrients and soil moisture. These findings are in line with previous studies which highlighted that growing leguminous crops such as beans and groundnuts, together with maize plants help to reduce soil degradation, therefore, adding nitrogen to the soil (Singh et al. 2017; Wolz and Delucia 2018). The practice of mixed cropping is better than monocropping, similar findings were obtained from the studies by Makuvaro et al. (2018) reported that monocropping is a poor technique in farming. Therefore, cultivating the same similar crops on the same plot year after year leads to pests and disease outbreaks and concentrates nutrient uptake from the same soil depth, leading to nutrient depletion. While in Vhembe district, local farmers said, mixed cropping of cowpea, Bambara groundnuts and maize was needed by the soil as they have a significant ability to fix nitrogen in the soil. Also, considered as green manure" as they increase soil fertility.

Furthermore, small-scale farmers practice this technique to guarantee some harvests in the event other crops fail due to climate shocks. A study conducted by (Mngumi 2016) in Tanzania reported that most cultivated fields within the study area were characterised by two or more crop types dependent on 
the farmer's preferences and farm location. A similar study in Western Australia by Ghahramani and Bowran (2018) argued that mixed farming methods have attributes that can be adopted for case studies on the awareness of impacts climate variability and change on agricultural production. Crop production on dryland area in Vhembe District was characterized by intercropping of predominantly maize with pulses of Bambara groundnut, beans and groundnuts with local pumpkins.

As the result of the findings reveals, farmers in the district practise mixed cropping methods to ensure a good harvest, in case some crops do not produce or fail. Further, farm size is also necessary for this type of farming system. During field survey, it was observed that most of the farms land in the study sites were cultivated with more crops, depending on the farmers' choice and farms location. It was noticed that more of the crop grown in Nwanedi were drought resistant, such as beans, tomatoes and okra. This argument is in line with empirical evidence for various literatures thus concluded in their studies that growing both trees and crops on the same farms land has the benefit of decreasing risk of evapotranspiration during extreme heat wave (Beedy et al. 2010; Magrini et al. 2016). This is possible for Nwanedi farmers, as the study area is location under semi-arid ecological zone with high temperature.

\section{Small-scale irrigation}

Furthermore, Intensification of the small-scale furrow and sprinkler irrigation was one of the vital methods employed by household farmers to adapt to the current decline in rainfall and increase in temperature in the past 30 years. However, most of the respondents in Tshiombo use furrow irrigation activities. The Tshiombo Irrigation Scheme was initiated in June 1962. The chiefs and the government allocated each resident of Tshiombo a plot of 1.286 hectares as agreed by the government and the local people. However, some residents were able to register for more than one plot because of nepotism. The irrigation technique was carried-out along the rivers, streams and few modernly constructed water reservoirs. In Tshiombo, farmers irrigated their farm plots of vegetable gardens and maize. The findings agree with the study in Oman, where small-scale farmers have taken chance to plant their crops with the aid of drip irrigation before the onset of the rainy period (Choudri et al. 2013). On the other hand, Bastakoti et al. (2014) in their study in Vietnam, argue that, local farmers planted their rice in the dry season to avoid salinity.

Tshiombo is different from Levubu and Nwanadi due to Tshiombo irrigation scheme. The study revealed that the irrigation activities have been going on at Tshiombo since 1962 irrigating approximately 1100 ha, with water being diverted from the Mutale River into a canal from the river using a weir, so the farmers had enough water for irrigation purposes. Small-scale farmers, as well as extension workers, acknowledge that another adaptation approach included increased focus on small-scale irrigation and irrigation schemes than waiting for rain-fed agriculture, which was a common method used by farmers in the previous 30 years. The results show that small-scale farmers who have water produce better agricultural products compared to small-scale farmers who are farming dryland areas. This findings agrees with Alam et al. (2017) who concluded that in Bangladesh, local farmers take advantage of the rainy season and planted crops during this wet season. The result of the findings has shown that irrigation techniques are important for improving and bettermanaging crop production, reducing food insecurity, increasing throughput and enhancing livelihoods in the district. This result is in line with the findings of studies conducted in Bangladesh (Keshavarz et al. 2014; Alam et al. 2017; Tripathi and Mishra 2017).

Indicators used to estimate choice of small-scale farmers' adaptation strategies to climate change

This study used MNL models to estimate drivers affecting choice of climate change adaptation methods by household farmers. MNL model is necessary in this study as it is useful for analysing farmer's adaptation decision due to their nature of been interchangeable. MNL model and marginal effects of this study is indicate in Tables 3 and 4 respectively.

Table 5 uses the Multinomial Logit Framework analysis, its show that the following indicators have significant influence of farmers' adaptation to climate change. These, indicators include; educational background, gender of household head, off-farm income, farm size in hectares, access to climate knowledge, and decline in rainfall and as well as temperature increase. Similar results were highlighted in studies 


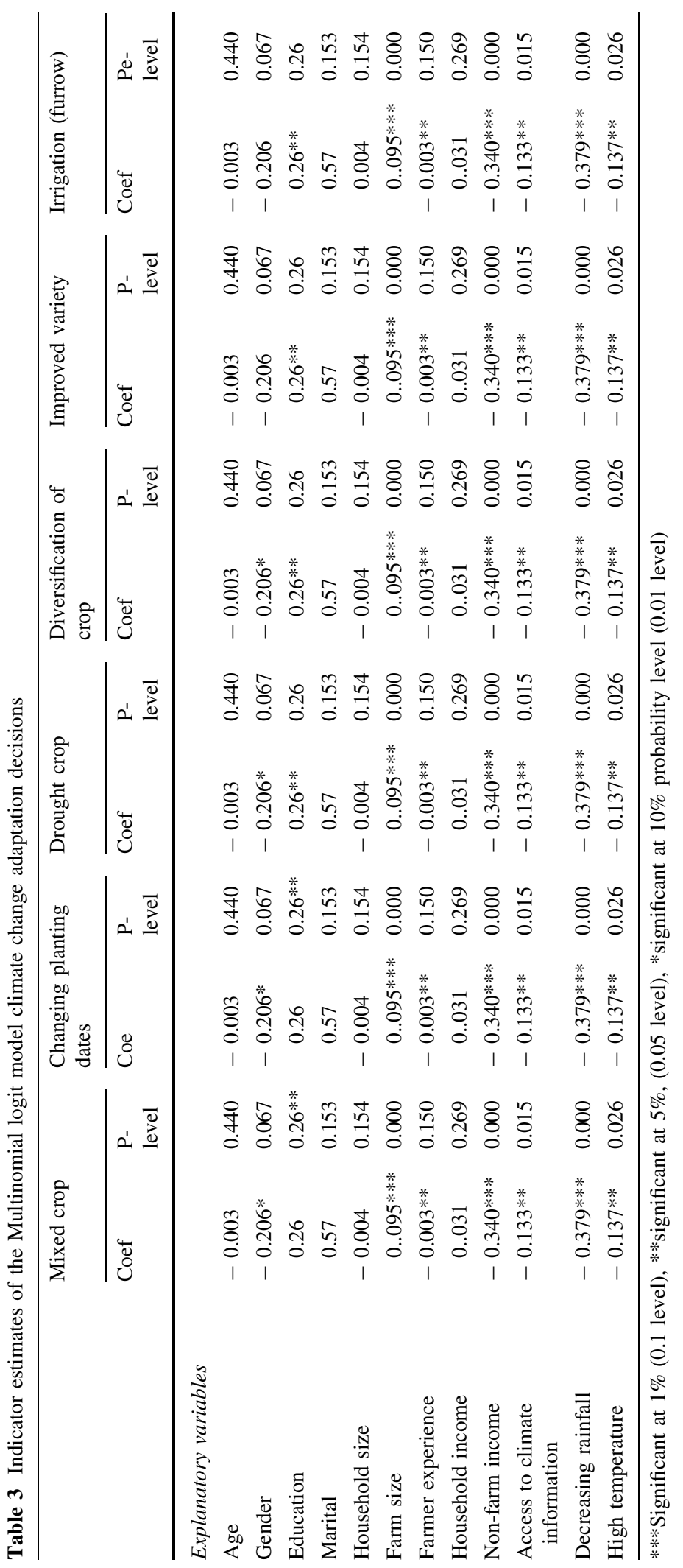




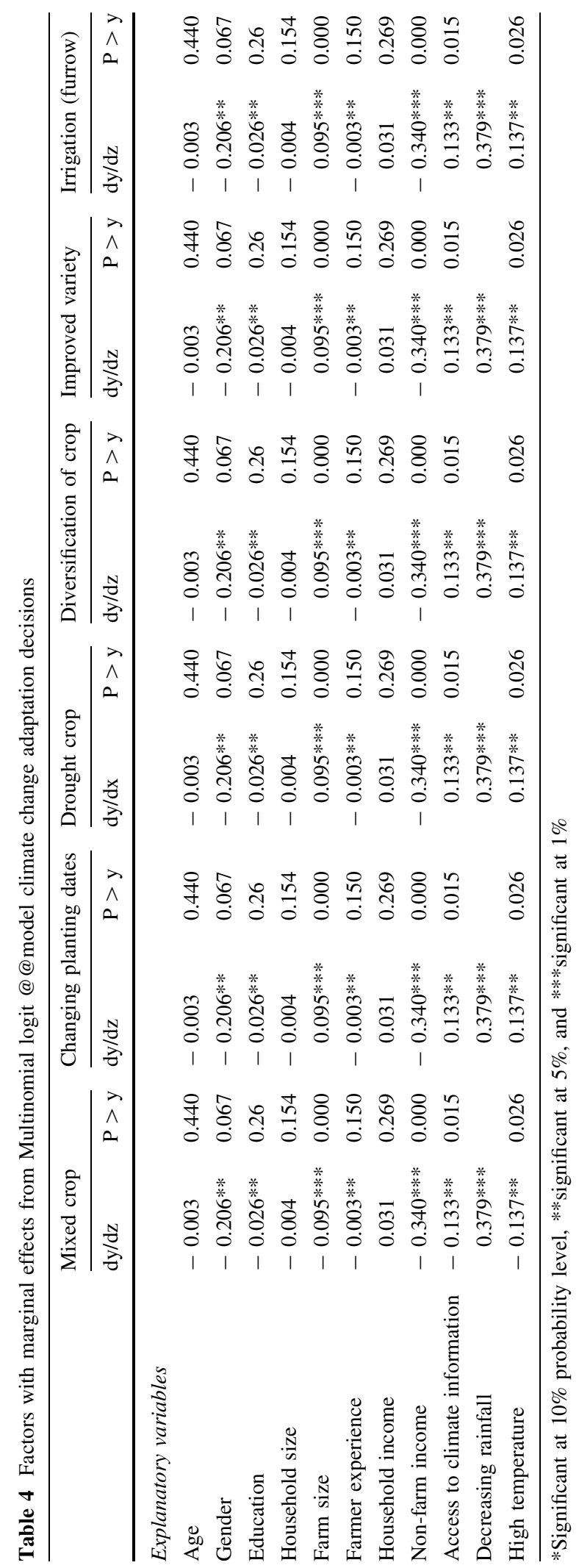




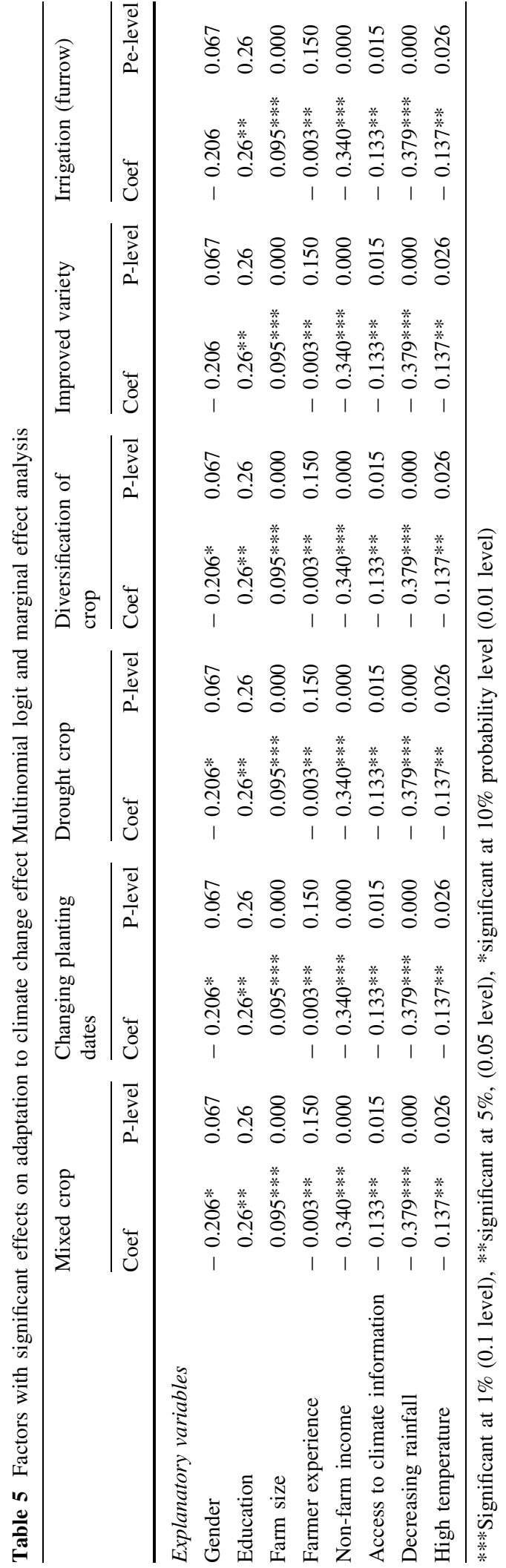

conducted by other research such as by Zizinga et al. (2017) Alemayehu and Bewket (2017).

The results of the study further indicated that out of the 224 respondents, $55.2 \%$ were female and only $44.8 \%$ were male. As indicated earlier on female farmers were mostly likely to employed new crops as a strategy of adaptation to climate change, is in lines with a study by Nhemachena and Hassan (2007) which could help to reduce negative impacts to climate variations. Further, the possible reason is that most of the farming work is done by women, while men are busy in off-farm activities in the study area, like seeking job in urban areas. This finding disagrees with that Adégnandjou and Barjolle (2018) who found that men are the majority of small-scale farmers and women involves in processing activities like trade in Zou department of Benin. Therefore, gender variation represents a significance of 0.01 level in response to change in climate. Farm size adoption in this study has a positive effect on climate change, with larger farms size playing a positive role in the decision to climate variability and change adaptation. However, an increase in farm size encourages farmers to practice diversification of crop activities and animal husbandry suitable to climate variability and change (Lemma 2016; Alemayehu and Bewket 2017).

The results of the findings revealed that a significance of $1 \%$ of farm size indicated as an adaptation determinant choice to climate change. Further, these results confirmed that in the context of this study, 0.05 significance effect of off-farm employed a change in adoption to climate variability. However, most offfarm activities in the study area adapt to climate impacts. The findings also showed that remittance was one of the most significant income sources for most small-scale farmers, which enhanced their livelihoods beyond farming. On the other hand, purchasing chemical farm inputs was done due to lack of capital from households, as highlighted in study conducted by Adégnandjou and Barjolle (2018).

The findings further reveal that knowledge about climate, however, plays a vital role in farmers' awareness on decreasing precipitation and temperature increased as well as higher level of education were complementing drivers that impact of the implementation of different techniques that could improve resilience against climate variability and change effects. This finding is in line with previous study conducted in Asian by analysis local farmers' 
adaptation strategies in response to changes in climate (Shaffril et al. 2018).

During data presentation, it was revealed that as much as there are some similarities in terms of adaptation strategies, the study area was dominated by slightly different climatic conditions and crops characterizing not only farmers' favourites, but further, because of socio-economic, local climatic conditions and small-scale irrigation. Looking at the conditions in Levubu and Tshiombo, genetically modified maize has been widely adopted as the main crop because of its capability to severe weather conditions, particularly prolonged dry spells. A similar situation in Zimbabwe documented by Cairns et al. (2013) reported that the recurrence of dry spells and lack of access to irrigation resources led to the development of drought-resistant (DT) maize varieties and its widespread adoption. In a similar study conducted in Brazil, maize was considered as the crop the highest yield and could be grown in both tropics and sub-tropics and to a certain extent in the semiarid area under harsh climatic conditions with adequate water as Kakumanu et al. (2016), thus conclude that farmers in China and Bangladesh used supplemental irrigation to boost crop production during long drought spell period. While studies conducted in Asia, reported that, small-scale farmers cultivated their crops near water bodies as the nearby water sources can reduce a lot of cost and easy crops irrigation (Keshavarz et al. 2014; Masud et al. 2017). The results of the findings agree with Yin et al. (2016), who stated that small-scale households' farmers with well advance irrigation scheme have a better plan to adapt to drought spell than those farmers still depending on out-dated irrigation method. Farmers in Tshiombo rely on the old traditional irrigation system, which results to poor crop production.

The findings further revealed significant similarities between the different areas, as most farmers have resorted to new and diverse crop varieties instead of the common varieties, due to different in ecological zones. However, a dissimilar situation was reported for Nwanedi, as most farmers have always been producing tomatoes and watermelons. On the other hand, traditional crops such as maize and sweet potatoes are under no threat from the perceived impacts of climate change as farmers have been proactive. Most small-scale farmers were able to adapt timeously and adopted more resistant, higher yield and shorter cycle crop varieties. These results are in line with the findings of Garcia de Jalon et al. (2018), reported that, in East Africa, local farmers were introducing crop resistant varieties as a common adopted measure, whereas in West Africa, changing planting dates was a measure of frequent adoption. Concerning maize cultivation, it was done through the introduction of new hybrid maize species, which are believed to have shortened cycle from planting to harvest due to increase in temperature conditions. This result of the findings disagrees with Olesen et al. (2012), stated that, the expected increase in temperature in the future will bring about growth of grain crops, as the crops starts growing and develop faster. The previous findings conducted, disagree with this finding, which stated that, maize production in Scandinavian nations, indicates a great increased production, as a result of increase in temperature conditions (Odgaard et al. 2011; Rasmussen et al. 2018). In this study, one of the extension officers clarified about this issue during the interview and focus group discussion; as he stated that most farmers' households have adopted new and better maize varieties which are more tolerant to the unfavourable weather conditions especially increase in temperature. Similar findings were obtained from the study done by (Rasmussen et al. 2018). In addition, the new crop varieties have shorter cycles than previously cultivated traditional crops (Ramesh et al. 2017). Several studies in Southern Africa and South Asia have yielded similar results, Tesfaye et al. (2018) stated in their studies of possible benefits of drought tolerant maize for adapting to climate change in tropical regions.

Hence, another finding of adaptation strategy that has been adopted by the small-scale farmers across the three ecological zone was crops diversification. The findings from the study have shown that there are four main crops been cultivated. These include maize (improved varieties), Irish potatoes, vegetables, and tomatoes. According to Maddison (2006) the cultivation of multiple crop varieties is regarded as the most widespread adaptation strategy adopted across Africa (Olubode 2019). Nonetheless, the study found that the strategy was not evenly spread across regions for instance crop varieties with shorter cycles were more preferable in West Africa (Olubode 2019). On the contrary, findings from South Africa indicated that the adaptation strategy is not differentially demarcated spatially, with exceptions only in the type of crops preferred. Li et al. (2013), highlighted that crop 
diversification methods helped farmers to overcome the challenges of poor productivity, while the same season generate extra resources and reduced the hazard of corps from failure of one particular crop.

Further, this study discussed the diversification techniques aimed to diversify income from farmers' activities from the farms to off-farm, to combat climate variability and change. According to the heterogeneous nature in the study area, farmers participated in various income-generating activities. A similar study by Bryceson (2019), revealed that diversification of household livelihoods activities, management arrangements, altering farming activities, income generation schemes, trading of labour and the shifting to non-farm livelihood incomes were a more prominent adaptation strategy within Sub Sahara Africa. However, it varied so much from one study area to another, in accordance with the area level, $76.6 \%$ of the respondents in Levubu were engaged in various alternative income generating activities. In Tshiombo it was $79.6 \%$, while in Nwanedi the respondents accounted for $72.6 \%$. The study showed that most small-scale household farmers have been evolving in changing adaptation strategies in response to climate change.

\section{Conclusions}

This study indicate how climate variability and change influenced small-scale farmers to employ coping and adaptation strategies at the local farm level. However, the study revealed, changes that farmers within the study sites have been making for adapting to climate change. Focus group discussions, questionnaires, and interviews were used as data collection techniques.

Hence, it was revealed that, adaptation is the process of recognising the impacts of climate change and adapting to the changed conditions. Due to the perceived impacts of climate change, farm households have adopted on-farm activities as a means of enhancing their resilience to climate change. The results from this study indicated that small-scale farmers are building effort to adapt to climate variation effects on crop yield. Indeed, farmers showed that to reduce the gaps associated with climatic shocks they use several crop varieties, drought resistant crops, shorter cycle crops, intensifying and furrow irrigation.
In line with the results of this study, adaptation strategies through understanding significant determinants of small-scale' farmers' choice is important to design impactful adaptation strategies in the study area. The relationship between the exploratory variable and dependent variable was analysed using Multinomial logit Regression Framework. These adaptation strategies to climate variability and change indicated that socio-economic and physical variables influence the choice of farmers' household adoption ability. The significant determinant drivers affecting farmers' choice of adaptation methods include: educational level of household head, landholding size, available information to climate change, off-farm activities, decrease and increase of rainfall and temperature respectively.

Therefore, climate change adaptation techniques success would largely rely on the accessibility of a strong and well-designed intuitional planning characterised by high combination. The governmental Department and community drivers further play an important role in structuring the extent to which farmers and societies are vulnerable to different climatic hazards. The tactical and strategic planning that is fashioned at the national level should be from grass root level (farm-level) to National-level approached with a clear instruction, accountability and provision of sufficient financial capital. Hence, it is necessary to identify the strength and holes on how the different stakeholders are planning and the ways they coordinate their activities with the local households and community. However, it is vital that each investor should be directed to carried-out its mandate with maximum precaution and total responsibility.

Acknowledgements The authors are grateful for the financial support from National Research Foundation (NRF) South Africa, Research and Innovation Office University of Venda, South Africa and Water Research Commission, South Africa (Grant No. SES/17/GGIS/01). They are also grateful to the small-scale farmers in Vhembe District who participated in the survey and with data provided by the South Africa Weather Services. We really also acknowledge the field assistants.

\section{Compliance with ethical standards}

Conflict of interest All authors contribution were significant and no conflict of interest.

Open Access This article is licensed under a Creative Commons Attribution 4.0 International License, which permits use, sharing, adaptation, distribution and reproduction in any 
medium or format, as long as you give appropriate credit to the original author(s) and the source, provide a link to the Creative Commons licence, and indicate if changes were made. The images or other third party material in this article are included in the article's Creative Commons licence, unless indicated otherwise in a credit line to the material. If material is not included in the article's Creative Commons licence and your intended use is not permitted by statutory regulation or exceeds the permitted use, you will need to obtain permission directly from the copyright holder. To view a copy of this licence, visit http://creativecommons.org/licenses/by/4.0/.

\section{References}

Acquah, H. D. (2011). Farmers' perception and adaptation to climate change effects: A willingness to pay. Journal of Sustainable Development in Africa, 13(5), 150-161.

Adégnandjou, M. R. F., \& Barjolle, D. (2018). Farmers' adaptation strategies to climate change and their implications in the Zou Department of South Benin. Environments, 5, $15-24$.

Adger, W. N., Kelly, P. M., \& Ninh, N. H. (2001). Living with environmental change: Social resilience, adaptation, and vulnerability in Vietnam. London: Routledge.

AGRA. (2013). Africa Agriculture Status Report: Focus on stable crops. File:///C:/Users/zanele/Downloads/annualreport-2013.pdf. Accessed 2 March 2018.

Alam, G. M. M., Alam, K., \& Mushtaq, S. (2017). Climate change perceptions and local adaptation strategies of hazard-prone rural households in Bangladesh. Climate Risk Management, 17, 52-63.

Alemayehu, A., \& Bewket, W. (2017). Determinants of smallholder farmers' choice of coping and adaptation strategies to climate change and variability in the central highlands of Ethiopia. Environmental Development, 22(7), 77-85.

Anderson, S., Gundel, S. M., \& Vanni, M. (2010). The impacts of climate change on food security in Africa: A synthesis of policy issues for Europe. London: International Institute for Environment and Development.

Ayanlade, A., Radeny, M., \& Morton, J. (2017). Comparing smallholder farmers' perception of climate change with meteorological data: A case study from southwestern Nigeria. Weather and Climate extremes, 15, 24-33.

Balew, S., Agwata, J., \& Anyango, S. (2014). Determinants of adoption choices of climate change adaptation strategies in crop production by small scale farmers in some Region of Central Ethiopia. Journal of Natural Sciences Research, 4(4), 1-16.

Banerjee, R. R. (2015). Farmers' perception of climate change, impact and adaptation strategies: A case study of four villages in the semi-arid regions of India. Natural Hazards, 75(3), 2829-2845.

Barton, M. G., Terblancle, J. S., \& Sinclair, J. B. (2019). Incorporating temperature and precipitation extremes into process-based models of African lepidoptera changes the predicted distribution under climate change. Ecological Modelling, 394, 53-65.

Bastakoti, R. C., Gupta, J., Babel, M. S., \& van Dijk, M. P. (2014). Climate risks and adaptation strategies in the
Lower Mekong River basin. Regional Environmental Change, 14(1), 207-219.

Beedy, T., Snapp, S., Akinnifesi, F., \& Sileshi, G. (2010). Impact of Gliricidia sepium intercropping on soil organic matter fractions in a maize-based cropping system. Agriculture, Ecosystems \& Environment, 138, 139-146.

Bryceson, F. D. (2019). Gender and generational patterns of African deagrarianization: Evolving labour and land allocation in smallholder peasant household farming, 1980-2015. World Development, 113, 60-72.

Burton, I., Diringer, E., \& Smith, J. (2006). Adaptation to climate change: International policy options. Report for the Pew Center on Global Climate Change, November, 2006, Arlington, USA. http://www.pewclimate.org.

Buyinza, M., \& Wambede, N. (2008). Extension of agroforestry technology adoption: Mixed intercropping of crotalaria (Crotaloria grahamiana) and maize (Zea mays L.) in Kabale District, Uganda. Environmental Research Journal, 2(3), 131-137.

Cairns, J. E., Crossa, J., Zaidi, P. H., Grudloyma, P., Sanchez, C., \& Araus, J. L. (2013). Identification of drought, heat and combined drought and heat tolerance donors in maize (Zea mays L.). Crop Science, 53, 1335-1346.

Chazovachii, B. (2012). The impact of small scale irrigation schemes on rural livelihoods: The case of Panganai irrigation scheme Bikita District Zimbabwe. Journal of Sustainable Development in Africa, 14, 217-231.

Choudri, S., Al-Busaidi, B., \& Ahmed, M. (2013). Climate change, vulnerability and adaptation experiences of farmers in Al-Suwayq Wilayat, Sultanate of Oman. International Journal of Climate Change Strategies and Management, 5(4), 445-454.

Dedewrwaerdere, T., \& Hannachi, M. (2019). Socio-economic drivers of coexistence of landraces and modern crop varieties in agro-biodiversity rich Yunnan rice fields. Ecological Economics, 159, 177-188.

Deressa, T. T., Hassan, R. M., Ringler, C., Alemu, T., \& Yesuf, M. (2009). Determinants of farmer's choice of adaptation methods to climate change in the Nile Basin of Ethiopia. Global Environmental Change, 19, 248-255.

Devi, E. L., Devi, C. P., Kumar, S., Sharma, S. K., Beemrote, A., Chongtham, S. K., et al. (2017). Marker assisted selection (MAS) towards generating stress tolerant crop plants. Plant Gene, 11(part B), 205-218.

Domenech, L. (2015). Improving irrigation access to combat food insecurity and undernutrition: A review. Global Food Security, 6, 24-33.

Epule, E. T., Ford, D. J., Lwasa, S., \& Lepage, L. (2017). Climate change adaptation in the Sahel. Environmental Science \& Policy, 75, 121-137.

Eyshi Rezaei, E., Webber, H., Gaiser, T., Naab, J., \& Ewert, F. (2015). Heat stress in cereals: Mechanisms and modeling. European Journal of Agronomy, 64, 98-113.

FAO. (2008). Climate change adaptation and mitigation in the food and agriculture sector. Rome: FAO.

FAO, IFAD and WFP. (2015). The state offood insecurity in the world 2015. Meeting the 2015 international hunger targets: Taking stock of uneven progress, Food and Agriculture Organisation Publications, Rome (inserted reference).

Fisher, H. W., Reddy, N. N. L., \& Rao, M. L. S. (2016). Can more drought resistant crops promote more climate secure 
agriculture? Prospects and challenges of millet cultivation in Ananthapur, Andhra Pradesh. World Development Perspectives, 2, 5-10.

Gandure, S., Walker, S., \& Botha, J. J. (2013). Farmers' perceptions of adaptation to climate change and water stress in a South African rural community. Environmental Development, 5(1), 39-53.

Garcia de Jalon, S., Iglesias, A., \& Neumann, M. B. (2018). Responses of sub-Saharan smallholders to climate change: Strategies and drivers of adaptation. Environmental Science \& Policy, 90, 38-45.

Ghahramani, A., \& Bowran, D. (2018). Transformative and systemic climate change adaptation in mixed crop-livestock farming systems. Agricultural Systems, 164, 236-257.

Gunathilaka, R. P. D., Smart, C. R. J., \& Fleming, M. C. (2018). Adaptation to climate change in perennial cropping systems: Options, barriers and policy implications. Environmental Science \& Policy, 82, 108-116.

Hammer, G. L., Kropff, M. J., Sinclair, T. R., \& Porter, J. R. (2002). Future contributions of crop frameworkling - from heuristics and supporting decision making to understanding genetic regulation and aiding crop improvement. European Journal of Agronomy, 18, 15-31.

Hassan, R., \& Nhemachena, C. (2008). Determinants of African farmers' strategies for adaptation to climate change: Multinomial choice analysis. African Journal of Agricultural and Resource Economics, 2(1-22), 83-104.

Hill, A. (2008). Fairness in adaptation to climate change. Development in Practice, 18(1), 141-143.

Hou, L. L., Huang, J. K., \& Wang, J. X. (2015). Farmers' perceptions of climate change in China: The influence of social networks and farm assets. Climate Research, 63, 191-201.

Hu, X., Huang, Y., Sun, W., \& Yu, L. (2017). Shifts in cultivar and planting date have regulated rice growth duration under climate warming in China since the early 1980s. Agricultural and Forest Meteorology, 247, 34-41.

Intergovernmental Panel on Climate Change (IPCC). (2007). Fourth assessment report: Climate change (AR4) Chapter 8: Agriculture.

Intergovernmental Panel on Climate Change (IPCC). (2010). Managing the risks of extreme events and disasters to advance climate change adaptation. In A special report on Working Group I and Working Group II of the Intergovernmental Panel on Climate Change. http://www.ipcc.ch/ ipccreports/ar4-system. Accessed 2 March 2018.

Intergovernmental Panel on Climate Change (IPCC). (2011). Managing the risks of extreme events and disasters to advance climate change adaptation. In A special report on Working Group I and Working Group II of the Intergovernmental Panel on Climate Change. http://www.ipcc.ch/ ipccreports/ar4-system. Accessed 2 March 2018.

Intergovernmental Panel on Climate Change (IPCC) (2014). Porter, J. R., Xie L., Challinor, A. J., Cochrane, K., Howden, S. M. Iqbal, M. M., Lobell, D. B., \& Travasso, M. I. (2014). Food security and food production systems. In C. B. Field, V. R. Barros, D. J. Dokken, K. J. Mach, M. D. Mastrandrea, T. E. Bilir, M. Chatterjee, K. L. Ebi, Y. O. Estrada, R. C. Genova, B. Girma, E. S. Kissel, A. N. Levy, \& S. MacCracken (Eds.), Climate change 2014:
Impacts, adaptation, and vulnerability. Part A: Global and sectoral aspects. Contribution of Working Group II to the Fifth Assessment Report of the Intergovernmental Panel on Climate Change.

International Fund for Agriculture Development (IFAD). (2008). Challenges and opportunities for smallholder farmers in the context of climate change and new demands on agriculture. http://www.ifad.org/events/gc/31/ roundtable/proceedings.pdf. Accessed 19 January 2019.

Jianjun, J., et al. (2015). Land use policy farmers' risk preferences and their climate change adaptation strategies in the Yongqiao District, China. Land Use Policy, 47, 365-372.

Jones, R. (2001). An environmental risk assessment/management framework for climate change impact assessment. Natural Hazards, 23, 197-230.

Kabanda, T. A. (2004). Climatology of long-term drought in the Northern region of the Limpopo Province of South Africa. Unpublished $\mathrm{PhD}$ thesis. University of Venda.

Kahinda, J. M., \& Taigbenu, A. E. (2011). Rainwater harvesting in South Africa: Challenges and opportunities. Physics and Chemistry of the Earth Parts A/B/C, 36(14), 968-976.

Kakumanu, K. R., Kuppanan, P., Ranganathan, C. R., Shalander, K., \& Amare, H. (2016). Assessment of risk premium in farm technology adoption as a climate change adaptation strategy in the dryland systems of India. International Journal of Climate Change Strategies and Management, 8(5), 689-717.

Karakaya, E., Hidalgo, A., \& Nuur, C. (2014). Diffusion of ecoinnovations: A review. Renewable and Sustainable Energy Reviews, 33, 392-399.

Keshavarz, M., Karami, E., \& Zibaei, M. (2014). Adaptation of Iranian farmers to climate variability and change. Regional Environmental Change, 14(3), 1163-1174.

Komba, C., \& Muchapondwa, E. (2012). Adaptation to climate change by smallholder farmers in Tanzania. Tanzania: Economic Research Southern Africa.

Komba, C., \& Muchapondwa, E. (2015). Adaptation to climate change by smallholder farmers in Tanzania. Discussion Study Series EfD DP 15-12, Environment for Development Centers.

Lemma, A. W. (2016). Analysis of smallholder farmers' perceptions of climate change and adaptation strategies to climate change: The case of Western Amhara Region, Ethiopia. Ph.D. Thesis.

Li, C., Tang, Y., Luo, H., Di, B., \& Zhang, L. (2013). Local farmers' perceptions of climate change and local adaptive strategies: A case study from the middle Yarlung Zangbo River Valley, Tibet, China. Environmental Management, 52, 894-906.

Loison, R., Audebert, A., Chopart, J. L., Debaeke, P., Dessauw, D., Gourlot, J. P., et al. (2017). Sixty years of breeding in Cameroon improved fibre but not seed cotton yield. $E x$ perimental Agriculture, 53(2), 202-209.

Maddison, D. (2006). The perception of and adaptation to climate change in Africa. CEEPA Discussion Study No. 10. Centre for Environmental Economics and Policy in Africa, University of Pretoria.

Magombo, T., Kanthiti, G., Phiri, G., Kachulu, M., \& Kabuli, H. (2011). Incidence of indigenous and innovative climate change adaptation practices for smallholder farmers' 
livelihood security in Chikhwawa District, Southern Malawi. African Technology Policy Studies Network.

Magrini, M.-B., Anton, M., Cholez, C., Corre-Hellou, G., Duc, G., Jeuffroy, M.-H., et al. (2016). Why are grain-legumes rarely present in cropping systems despite their environmental and nutritional benefits? Analyzing lock-in in the French agrifood system. Ecological Economics, 126, 152-162.

Makuvaro, V., Walker, S., Masere, T. P., \& Dimes, J. (2018). Smallholder farmer perceived effects of climate change on agricultural productivity and adaptation strategies. Journal of Arid Environments, 152, 75-82.

Maponya, P. I. (2013). Climate change and agricultural production in Limpopo: Impacts and adaptation options $(\mathrm{PhD}$ thesis, P.108) Environmental Management, University of South Africa, Pretoria, South Africa.

Maponya, P., \& Mpandeli, S. (2013). Coping with climate change variability in Limpopo province, South Africa. Peak Journal of Agricultural Science, 4, 54-64.

Masud, M. M., Azam, M. N., Mohiuddin, M., Banna, H., Akhtar, R., Alam, A. S. A. F., et al. (2017). Adaptation barriers and strategies towards climate change: Challenges in the agricultural sector. Journal of Cleaner Production, 156, 698-706.

Menike, L., \& Arachchi, K. K. (2016). Adaptation to climate change by smallholder farmers in rural communities: Evidence from Sri Lanka. Procedia Food Science, 6, 288-292.

Mkonda, M., He, X., \& Festin, E. S. (2018). Comparing smallholder farmers' perception of climate change with meteorological data: Experience from seven agro ecological zones of Tanzania. Weather, Climate and Society, 4(3), $59-72$.

Mngumi, J. (2016). Perceptions of climate change, environmental variability and the role of agricultural adaptation strategies by small-scale farmers in Africa: The case of Mwanga district in northern Tanzania. Ph.D. thesis.

Mpandeli, N. S. (2006). Coping with climate variability in Limpopo Province (Unpublished $\mathrm{PhD}$ thesis). University of Witwatersrand.

Mpandeli, S., Nesamvuni, E., \& Maponya, P. (2015). Adapting to the impacts of drought by smallholder farmers in Sekhukhune District in Limpopo province, South Africa. Journal of Agricultural Science, 7(2), 115-124.

Mubiru, D. N., Kyazze, F. B., Radeny, M., Zziwa, A., Lwasa, J., \& Kinyangi, J. (2015). Climatic trends, risk perceptions and coping strategies of smallholder farmers in rural Uganda.

Municipal Demarcation Board. (2002). Retrieved 21 March, 2018 from http://www.demarcation.org.za.

Munyati, C., \& Kabanda, T. (2009). Using multi -temporal Landsat TM imagery to establish land use pressure induced trends in forest and woodland cover in sections of the Soutpansberg Mountains of Venda region, Limpopo Province, South Africa. Regional Environmental Change, 9, 41-56.

Nhemachena, C., \& Hassan, R. M. (2007). Micro-level analysis of farmers' adaptations to climate change in Southern Africa. IFPRI Discussion Study No 714, Washington D.C, IFPRI.
Niang, I., Ruppel, O., Abdrabo, M., Essel, A., Lennard, C., Padgham, J., et al. (2014). Africa. In Climate change 2014: Impacts, adaptation and vulnerability. Contribution of Working Group II to the Fifth Assessment Report of the Intergovernmental Panel on Climate Change. Cambridge University Press of Africa: Challenges, Opportunities and Impacts, African Climate Policy Centre Working Study 5, November 2011.

Nyong, A., Adesina, F., \& Elsasha, B. O. (2007). The value of indigenous knowledge in climate change mitigation and adaptation strategies in the African Sahel. Mitigation Adaptation Strategies Global Change, 12, 787-797.

Obayelu, O. A., Adepoju, A. O., \& Idowu, T. (2014). Factors influencing farmers' choices of adaptation to climate change in Ekiti State, Nigeria. Journal of Agriculture and Environment for International Development, 108(1), 3-16.

Odekunle, T., Balogun, E., \& Ogunkoya, O. (2005). On the prediction of rainfall onset and retreat dates in Nigeria. Theoretical and Applied Climatology, 81, 101-112.

Odgaard, M. V., Bøcher, P. K., Dalgaard, T., \& Svenning, J. C. (2011). Climatic and non-climatic drivers of spatiotemporal maize-area dynamics across the northern limit for maize production-A case study from Denmark. Agriculture, Ecosystems \& Environment, 142, 291-302.

Olesen, J. E., Børgesen, C. D., Elsgaard, L., Palouso, T., Rötter, R. P., Skjelvåg, A. O., et al. (2012). Changes in time of sowing, flowering and maturity of cereals in Europe under climate change. Food Additives \& Contaminants, 29, $1527-1542$.

Olubode, O. O. (2019). Influence of seasonal variability of precipitation and temperature on performances of pawpaw varieties intercropped with cucumber. Sciential Horticulturrae, 243, 622-644.

Oni, S. A., Nesamvuni, A. E., Odhiambo J. J., \& Dagada, D. C. (2012). Executive summary of a study of agricultural industry of Limpopo Province. Centre for Rural Development: Department of Soil Science, South Africa.

Perego, V. M. E. (2019). Crop prices and the demand for titled land: Evidence from Uganda. Journal of Development Economics, 137, 93-109.

Ramesh, K., Rao, A. N., \& Chauhan, B. S. (2017). Role of crop competition in managing weeds in rice, wheat, and maize in India: A review. Crop protection, 95, 14-21.

Rasmussen, S. B., Blenkinsop, S., Burton, A., Abrahamsen, P., Holm, P. E., \& Hansen, S. (2018). Climate change impacts on agro-climatic indices derived from downscaled weather generator. Scenarios for eastern Denmark. European Journal of Agronomy, 101, 222-238.

Saunders, M. N. (2011). Research methods for business students, 5/e, Pearson Education India.

Setimela, P. S., \& Kosina, P. (2006). Strategies for strengthening and scaling up community-based seed production. Mexico, D.F.: CIMMYT. ISBN: 970, 648-143-5.

Shaffril, M. A. H., Krauss, E. S., \& Samsuddin, F. S. (2018). A systematic review on Asian's farmers' adaptation practices towards climate change. Science of the Total Environment, 644, 683-695.

Singh, P., Boote, K. B., Kadiyalaa, M. D. D., Nedumarana, S., Guptaa, S. K., Srinivasa, K., et al. (2017). An assessment of yield gains under climate change due to genetic 
modification of pearl millet. Science of the Total Environment, 601-602, 1226-1237.

Singh, P., Nedumaran, S., Ntare, B. R., Boote, K. J., Singh, N. P., Srinivas, K., et al. (2014). Potential benefits of drought and heat tolerance in groundnut for adaptation to climate change in India and West Africa. Mitigation and Adaptation Strategies for Global Change, 19(5), 509-529.

Smit, B., \& Wandel, J. (2006). Adaptation, adaptive capacity and vulnerability. Global Environmental Change, 16(3), 282-292.

Statistics South Africa. (2011). Census (2011) Provinces at a glance. Pretoria: Statistics South Africa.

Tesfaye, K., Kruseman, G., Cairns, J. E., Zama-Allah, M., Wegary, D., Zaidi, P. H., et al. (2018). Potential benefits of drought and heat tolerance for adapting maize to climate change in tropical environments. Climate Risk Management, 19, 106-119.

Tripathi, A., \& Mishra, A. K. (2017). Knowledge and passive adaptation to climate change: An example from Indian farmers. Climate Risk Management, 16, 195-207.

Turpie, J., \& Visser, M. (2013).The impact of climate change on South Africa's rural areas. https://www.google.co.za/ search?q=THE+IMPACT $+\mathrm{OF}+\mathrm{CLIMATE}+\mathrm{CHANGE}+$ $\mathrm{ON}+\mathrm{SOUTH}+\mathrm{AFRICA} \% \mathrm{CA} \% \mathrm{BCS}+\mathrm{RURAL}+\mathrm{AREAS} \&$ rlz=1C1KMZB_enZA587ZA587\&oq=THE+IMPACT+ $\mathrm{OF}+\mathrm{CLIMATE}+\mathrm{CHANGE}+\mathrm{ON}+\mathrm{SOUTH}++\mathrm{AFRICA} \%$ $\mathrm{CA} \% \mathrm{BCS}+\mathrm{RURAL}+\mathrm{AREAS} \&$ aqs $=$ chrome. $69 \mathrm{i} 57 \&$ sourceid=chrome\&es_sm $=93 \&$ ie $=$ UTF- $8 . \quad$ Accessed 12 March 2018.

Twagiramaria, F., Tolo, C. U., \& Zinyengere, N. (2018). Chapter 4-Adaptation to and coping strategies for climate change and variability by rural farmers in Kigezi Highlands, Uganda. In Beyond agricultural impact. Multiple perspectives on climate change and agriculture in Africa (1 ed.)., pp. 5-75.

Uddin, M. N., Bokelmann, W., \& Dunn, E. S. (2017). Determinants of farmers' perception of climate change: A case study from the Coastal Region of Bangladesh. American Journal of Climate Change, 6, 151-165.

Uddin, M. N., Bokelmann, W., \& Entsminge, J. S. (2014). Factors affecting farmers' adaptation strategies to environmental degradation and climate change effects: A farm level study in Bangladesh. Climate, 2(4), 223-241.

United Nations Framework Convention on Climate Change (UNFCCC). (2010). Ecosystem-based approaches to adaptation: Compilation of information. Note by the secretariat. Available at: http://unfccc.int/resource/docs/2011/ sbsta/eng/inf08.pdf. Accessed 23 Jan 2019.

United Nations Framework Convention on Climate Change (UNFCCC). (2013) Institutional arrangement for national adaptation planning and implementation, thematic report: United nations framework convention on climate change.
Van Aalst, M., Cannon, T., \& Burton, I. (2008). Community level adaptation to climate change: The potential role of participatory community risk assessment. Global Environmental Change, 18, 165-179.

Vhembe District Municipality (VDM). (2012/2013). Integrated Development Plan Review.

Vincent, K. (2007). Uncertainty in adaptive capacity and the importance of scale. Global Environmental Change, 7(1), 12-24.

Waongo, M., Laux, P., \& Kunstmann, H. (2015). Adaptation to climate change: The impacts of optimized planting dates on attainable maize yields under rainfed conditions in Burkina Faso. Agricultural and Forest Meteorology, 205(1), 23-39.

Wolz, K. J., \& Delucia, E. H. (2018). Alley cropping: Global patterns of species composition and function. Agriculture, Ecosystems \& Environment, 252, 61-68.

Wood, A. S., Jina, S. A., Jain, M., Kristjanson, P., \& Defries, S. R. (2014). Smallholder farmer cropping decisions related to climate variability across multiple regions. Global Environmental Change, 25, 163-172.

World Bank. (2013). Employment in agriculture (percentage of total employment). Accessed 24 January 242019.

Yin, X., Olesen, J. E., Wang, M., Kersebaum, K. C., Chen, H., Baby, S., et al. (2016). Adapting maize production to drought in the Northeast Farming Region of China. European Journal of Agronomy, 77, 47-58.

Zhang, T. Y., Huang, Y., \& Yang, X. G. (2013). Climate warming over the past three decades has shortened rice growth duration in China and cultivar shifts have further accelerated the process for late rice. Global Change Biology, 19, 563-570.

Zhao, H. F., Fu, Y. H., Wang, X. H., Zhao, C., Zeng, Z. Z., \& Piao, S. L. (2016). Timing of rice maturity in China is affected more by transplanting date than by climate change. Agricultural and Forest Meteorology, 216, 215-220.

Zinyengere, N., Crespo, O., Hachigonta, S., \& Tadross, M. (2014). Local impacts of climate change and agronomic practices on dry land crops in Southern Africa. Agriculture, Ecosystems \& Environment, 197, 1-10.

Zizinga, A., Richard, Y. M., Kangalawe, A. A., Tenywa, M. M., Majaliwa, J., Saronga, N. J., et al. (2017). Analysis of farmer's choices for climate change adaptation practices in South Western Uganda, 1980-2009. Journal of Climate Change, 5, 89.

Publisher's Note Springer Nature remains neutral with regard to jurisdictional claims in published maps and institutional affiliations. 